Prace Komisji Geografii Komunikacji PTG Transport Geography Papers of Polish Geographical Society
20(1)/2017 2069515

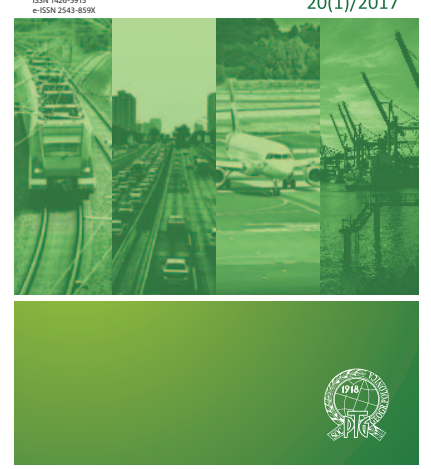

Prace Komisji Geografii Komunikacji PTG

2017, 20(1), 50-61

DOI 10.4467/2543859XPKG.17.004.6733

\title{
EWOLUCJA I ZRÓŻNICOWANIE SYSTEMÓW WIELOLOTNISKOWYCH NA ŚWIECIE
}

\section{Evolution and differentiation of multi-airport systems in the world}

\section{Piotr Trzepacz}

Instytut Geografii i Gospodarki Przestrzennej, Uniwersytet Jagielloński w Krakowie, Gronostajowa 7, 30-387 Kraków

e-mail: piotr.trzepacz@uj.edu.pl

\section{Cytacja:}

Trzepacz P., 2017, Ewolucja i zróżnicowanie systemów wielolotniskowych na świecie, Prace Komisji Geografii Komunikacji PTG, 20(1), 50-61.

Abstrakt: Systemy wielolotniskowe stanowią współcześnie konkurencyjne rozwiązanie dla koncepcji aerotropolis jako sposobu organizacji węzła komunikacji lotniczej wielkich miast. W ramach artykułu dokonano identyfikacji systemów wielolotniskowych na świecie. Przedstawiono cechy ich rozmieszczenia oraz wyniki analizy ścieżki rozwoju. Wzięto pod uwagę pierwotną funkcję obiektów tworzących taki system oraz ich przemiany. Dzięki temu możliwe było zarysowanie genezy systemów wielolotniskowych oraz ich zróżnicowania. Pracę kończy próba oceny walorów systemu wielolotniskowego w porównaniu z koncepcją aerotropolis.

Słowa kluczowe: węzły lotnicze, systemy wielolotniskowe, aerotropolis

Abstract: Multi-airport systems work as the competition for aerotropolis concept as the solution for organizing aviation nodes for great cities. As a part of the paper Author identified multi-airport systems in the world. Features of their location and the results of development paths analysis are presented. Author took under consideration primary functions of objects that build such system with their further transition. This approach gave the possibility to outline multi-airport systems genesis and differentiation. Paper is finished with the attempt to evaluate the advantages of multi-airport systems compared to the aerotropolis concept.

Keywords: aviation nodes, multi-airport systems, aerotropolis 


\section{Wstęp}

W literaturze dotyczącej badań nad funkcjonowaniem transportu lotniczego, w odniesieniu do grup obiektów obsługujących potrzeby transportowe w zakresie lotnictwa w skali miasta czy regionu, najczęściej stosowane są trzy określenia:

- system wielolotniskowy (ang. multi airport system - de Neufville 1995),

- miasto wielolotniskowe (ang. multi airport city Derudder i in. 2010),

- region wielolotniskowy (ang. multi airport region - Noruzoliaeea i in. 2015).

Pierwsze dwa pojęcia stosowane są zamiennie i odnoszą się do portów lotniczych, dla których wybrany obszar zurbanizowany jest wspólnym obszarem ciążenia'. W takim przypadku analizom poddaje się najczęściej czynniki decydujące o wyborze przez pasażerów konkretnego portu stanowiącego element takiego układu lub jak to ujmuje Maertens (2012), wyboru którejś z kombinacji „przewoźnik-port lotniczy". Autor ten słusznie zauważa, że w warunkach systemu wielolotniskowego najczęściej wybór przewoźnika determinuje wybór portu i odwrotnie. Jest to szczególnie widoczne w przypadku, gdy występuje konkurencja między portem głównym zdominowanym przez przewoźników tradycyjnych i portem drugorzędnym² dedykowanym przewoźnikom niskokosztowym. Wśród opracowań podejmujących to zagadnienie można znaleźć analizy funkcjonowania (głównie z perspektywy konkurencji) systemów wielolotniskowych m.in. Los Angeles (Ishii i in. 2009), Nowego Jorku (Ramanujam, Balakrishnan 2010), San Francisco (Harvey 1987; Hess, Polak 2005; Pels i in. 2003) i jego porównania z Bostonem oraz Waszyngtonem (Fuellhart i in. 2013). Zietsman i Vanderschuren (2014) poddali dyskusji potencjał Kapsztadu w zakresie rozwinięcia właśnie takiego rozwiązania.

Trzeci przywołany termin, czyli „region wielolotniskowy", stosowany jest najczęściej w przypadku, gdy przestrzenny aspekt konkurencji między portami lotniczymi nie dotyczy jednego ośrodka, ale obszaru oddziaływania kilku portów lotniczych, których obszary ciążenia nakładają się na siebie (Loo 2008; Postorino, Pratico 2012). W warunkach integracji europejskiej bezpośrednia konkurencja między portami lotniczymi może dotyczyć regionów należących do

Termin „obszar ciążenia” odpowiada stosowanemu W języku angielskim pojęciu "airport's catchment area" i oznacza obszar przyciągania pasażerów przez dany port lotniczy (Lieshout 2012).

2 W piśmiennictwie anglojęzycznym występuje najczęściej jako termin "secondary airport". różnych państw. Paliska i in. (2016) zwrócili uwagę na region Górnego Adriatyku, który stanowi wspólny obszar ciążenia dla portów lotniczych Ljubljany (Słowenia) oraz Wenecji i Triestu (Włochy).

Na potrzeby niniejszej pracy przyjęto definicję systemu wielolotniskowego przedstawioną przez Bonnefoy'a i in. (2008), gdzie stanowią go co najmniej dwa porty lotnicze obsługujące dany region metropolitalny. Warto podkreślić przestrzenne odniesienie stanowiące część tej definicji. Wyraźnie wskazuje ono na fakt, że mówiąc o obsłudze potrzeb transportowych danego ośrodka w zakresie lotnictwa należy brać pod uwagę jako odniesienie przestrzenne jego cały region metropolitalny a nie miasto postrzegane tradycyjnie jako jednostka ograniczona granicą administracyjną. Już wcześniej na potrzebę takiego właśnie podejścia zwracał uwagę de Neufville (1995). Za przykład podawał relacje Baltimore i Waszyngtonu, których centra oddalone są od siebie o 60 kilometrów. Zauważył on, że poprzez rozlewanie się obu miast doszło do utworzenia przez nie jednego regionu metropolitalnego generującego jeden wspólny rynek transportu lotniczego. W tym przypadku relacje między ośrodkami (Baltimore i Waszyngtonem) są na tyle skomplikowane, że trudno jednoznacznie wskazać, który z portów całego tego zurbanizowanego obszaru obsługuje które miasto. Fuellhart (2007) zauważył również, że rozwinięcia się w tym przypadku systemu wielolotniskowego (ani samego regionu metropolitalnego) nie ograniczał fakt dzielenia go przez granice stanowe.

Zgodnie z przedstawionymi wyżej rozważaniami, identyfikując systemy wielolotniskowe, należy uwzględnić dynamikę i charakter przestrzenny procesów kształtujących miasta i ich zaplecze. Nie ogranicza się to jedynie do efektów procesów takich jak urban sprawl. Rozwój miast generuje rosnące zapotrzebowanie na porty lotnicze o coraz większej przepustowości. Nowe inwestycje wypychane są najczęściej ku zewnętrznym krawędziom obszarów zurbanizowanych a czasami w ogóle poza nie (Trzepacz i in. 2012). Tym samym coraz częściej porty lotnicze obsługujące dane miasto położone są poza jego granicami administracyjnymi.

Z perspektywy obsługiwanego ośrodka, zróżnicowane pod względem oferowanej siatki połączeń i wykonujących ją przewoźników porty uzupełniają się, tworząc łącznie bogatszą ofertę. Należy jednak pamiętać, że porty w takim układzie szczególnie mocno konkurują o pasażerów (Loo 2008). Staje się to coraz ważniejszym aspektem funkcjonowania tego rodzaju węzłów lotniczych. Zauważa się odchodzenie przynajmniej niektórych przewoźników niskobudżetowych od ścisłej zależności od portów drugorzędnych. Coraz częściej rozbudowują one swoją ofertę 
o połączenia obsługiwane z portów centralnych również w sytuacji, gdy dany węzeł wyposażony jest w port wyspecjalizowany do obsługi tanich linii lotniczych. Wystarczy przywołać tutaj przykład przewoźnika Ryanair i jego działań w Polsce. Przewoźnik ten większość połączeń związanych z ośrodkiem stołecznym realizuje obecnie z portu dedykowanego przewoźnikom niskokosztowym w Modlinie. Jednocześnie z ofertą połączeń krajowych powrócił do portu centralnego.

Celem opracowania jest próba wskazania prawidłowości w rozwoju systemów wielolotniskowych i ich zróżnicowania na świecie. Na potrzeby analizy wybrano takie systemy, w przypadku których przynajmniej dwa porty oferują połączenia rozkładowe. Należy pamiętać, że nie wyczerpuje to okoliczności, w których ośrodek miejski może być obsługiwany przez więcej niż jeden obiekt infrastruktury transportu lotniczego. System portów lotniczych może mieć charakter układu portów wyspecjalizowanych do obsługi różnych typów transportu lotniczego. Może być to specjalizacja jednego z portów w zakresie pasażerskiego transportu lotniczego a w przypadku drugiego w zakresie transportu cargo: przykład Uljanowsk (port Baratayevka - pasażerskie, port Wostocznyj - cargo) a także wykorzystywanie jednego portu do celów komunikacyjnych a innego obiektu np. do celów sportowych.

\section{Geneza systemów wielolotniskowych świata}

Rozwój systemów wielolotniskowych może następować albo w powiązaniu z realizacją zupełnie nowych projektów inwestycyjnych, albo w oparciu o aktywizację (sukcesję) istniejącej infrastruktury transportu lotniczego. Powstanie systemu wielolotniskowego nie musi zatem oznaczać wzrostu liczby lotnisk. Biorąc pod uwagę fakt, że tworzenie nowych obiektów na cele obsługi transportu lotniczego jest wysoce terenochłonne, to wykorzystanie tych już istniejących należy uznać za rozwiązanie bardziej racjonalne. O tym czy faktycznie tak jest w dużej mierze decyduje jednak istniejące zagospodarowanie otoczenia takiego obiektu i jego lokalizacja. W przypadku Europy szczególną popularnością cieszy się rozwiązanie polegające na wykorzystaniu lotniska pełniącego dotychczas funkcje militarne. Tego rodzaju obiekty najczęściej zlokalizowane są poza obszarami gęstej zabudowy, co pozwala na wprowadzanie do ich otoczenia np. obiektów wielkopowierzchniowych infrastruktury okołolotniskowej. Pewien istotny problem stanowi organizacja transportu wiążącego taki obiekt o nowych funkcjach z centrum obsługiwanego układu osadniczego. Najczęściej są one bowiem znacznie oddalone od obszaru zurbanizowanego. Problem ten jednak potencjalnie może łagodzić możliwość zrewitalizowania dawnych linii kolejowych wykorzystywanych przez wojsko a doprowadzonych jeśli nie do samego lotniska, to w jego okolice w związku z funkcjonowaniem jednostki wojskowej (Kołoś i in. 2012).

Można wskazać dwa główne wzorce rozwoju systemów wielolotniskowych (tab. 1). Pierwszy z nich, charakterystyczny głównie dla Azji. powstaje w wyniku relokacji głównego portu lotniczego przy pozostawieniu części ruchu w lokalizacji pierwotnej. Zarówno w przypadku państw Dalekiego Wschodu jak i w państwach arabskich szczególną popularnością cieszą się rozwiązania typu aerotropolis. Najczęściej jednak ich realizacja nie oznacza całkowitego wyeliminowania wcześniejszej lokalizacji.

Drugi dominujący wzorzec to tworzenie systemu wielolotniskowego przez zaadaptowanie dla funkcji komunikacyjnych istniejących wcześniej lotnisk w przypadku Ameryki Północnej w drodze ewolucji lotnisk zdominowanych przez general aviation a w przypadku Europy najczęściej poprzez wykorzystanie obiektu wojskowego. Jest to zresztą praktyka nie ograniczająca się do systemów wielolotniskowych, ale znana już wcześniej w odniesieniu do portów regionalnych.

\section{Główne ścieżki ewolucji węzła lotniczego w kierunku systemu wielolotniskowego}

Rosnące potrzeby w zakresie mobilności lotniczej sprawiają, że porty lotnicze w coraz krótszym czasie osiągają taki poziom ruchu, który wymusza decyzje o dalszej rozbudowie obiektu (Martìn i in. 2011). Ze względu na potrzebę odprawiania coraz większej liczby pasażerów, których oczekiwania wobec takich obiektów również rosną, powstają kolejne coraz większe terminale. Zwiększająca się dynamicznie liczba operacji lotniczych sprawia natomiast, że buduje się kolejne drogi startowe. W ten sposób rozwój potrzeb transportowych także w przypadku lotnictwa cywilnego wiąże się z rosnącym zapotrzebowaniem na coraz większą przestrzeń niezbędną dla ich zaspokojenia. Jednak nie każda lokalizacja obiektu takiego jak port lotniczy pozwala na dowolny kierunek i skalę jego przestrzennej rozbudowy. W przypadku starych lokalizacji najczęściej szybko dochodzi do konfliktów przestrzennych między rosnącą aktywnością portu lotniczego a jego otoczeniem, które stało się np. obszarem dynamicznego rozwoju strefy podmiejskiej (Trzepacz, Luc 2015). Przekroczenie liczby odprawianych pasażerów odpo- 
Tab. 1. Geneza i zróżnicowanie systemów wielolotniskowych na świecie

\begin{tabular}{|c|c|c|}
\hline & Układ bez typowego secondary airport & Układ z typowym secondary airport \\
\hline \multicolumn{3}{|c|}{ A. Systemy dwulotniskowe } \\
\hline $\begin{array}{l}\text { A1. Wszystkie porty wyłącznie } \\
\text { z ruchem krajowym }\end{array}$ & & Norfolk (USA) \\
\hline $\begin{array}{l}\text { A2. Port z ruchem krajowym oraz } \\
\text { port z ruchem międzynarodowym }\end{array}$ & $\begin{array}{l}\text { Cleveland (USA), Johannesburg (RPA), Kolombo (Sri } \\
\text { Lanka), San Juan (Portoryko), Panama (Panama), } \\
\text { Windhoek (Namibia), Sapporo (Japonia), Tel Aviv } \\
\text { (Izrael), Teheran (Iran), Dżakarta (Indonezja), } \\
\text { Reykjavík (Islandia), Kopenhaga (Dania), San Jose } \\
\text { (Kostaryka), Medelin (Kolumbia), Pekin (Chiny), } \\
\text { Vancouver (Kanada), Toronto (Kanada), Montreal } \\
\text { (Kanada), Sao Paulo (Brazylia), Belo Horizonte } \\
\text { (Brazylia), Manila (Filipiny) }\end{array}$ & $\begin{array}{l}\text { Tampa (USA), St. Louis (USA), Phoenix } \\
\text { (USA), Orlando (USA), Houston (USA), Dallas } \\
\text { (USA), Meksyk (Meksyk), Rio de Janeiro } \\
\text { (Brazylia) }\end{array}$ \\
\hline $\begin{array}{l}\text { A3. Wszystkie porty z ruchem } \\
\text { międzynarodowym }\end{array}$ & $\begin{array}{l}\text { Dubaj (ZEA), Stambuł (Turcja), Tajpej (Tajwan), } \\
\text { Seul (Korea Południowa), Kuala Lumpur (Malezja), } \\
\text { Amman (Jordania), Tokio (Japonia), Szanghaj } \\
\text { (Chiny), Buenos Aires (Argentyna) }\end{array}$ & $\begin{array}{l}\text { Glasgow (Wielka Brytania), Belfast (Wielka } \\
\text { Brytania), Kijów (Ukraina), Bangkok } \\
\text { (Tajlandia), Göteborg (Szwecja), Warszawa } \\
\text { (Polska), Wenecja (Włochy), Rzym (Włochy), } \\
\text { Frankfurt nad Menem (Niemcy), Berlin } \\
\text { (Niemcy), Bruksela (Belgia) }\end{array}$ \\
\hline \multicolumn{3}{|c|}{ B. Systemy trójlotniskowe } \\
\hline $\begin{array}{l}\text { B1. Jeden port z ruchem } \\
\text { międzynarodowym, pozostałe } \\
\text { krajowe }\end{array}$ & Filadelfia (USA), Chicago (USA), Osaka (Japonia) & \\
\hline $\begin{array}{l}\text { B2. Dwa portu z ruchem } \\
\text { międzynarodowym, jeden z } \\
\text { krajowym }\end{array}$ & & Miami (USA) \\
\hline $\begin{array}{l}\text { B3. Wszystkie porty z ruchem } \\
\text { międzynarodowym }\end{array}$ & $\begin{array}{l}\text { San Francisco (USA), Waszyngton (USA), Moskwa } \\
\text { (Rosja) }\end{array}$ & $\begin{array}{l}\text { Barcelona (Hiszpania), Oslo (Norwegia), } \\
\text { Mediolan (Włochy), Paryż (Francja) }\end{array}$ \\
\hline \multicolumn{3}{|c|}{ C. Systemy czterolotniskowe } \\
\hline $\begin{array}{l}\text { C1. Jeden port z ruchem } \\
\text { międzynarodowym, pozostałe } \\
\text { krajowe }\end{array}$ & Melbourne (Australia) & Boston (USA) \\
\hline $\begin{array}{l}\text { C2. Wszystkie porty z ruchem } \\
\text { międzynarodowym }\end{array}$ & & Sztokholm (Szwecja) \\
\hline \multicolumn{3}{|c|}{ D. Systemy pięciolotniskowe } \\
\hline $\begin{array}{l}\text { D1. Dwa porty z ruchem } \\
\text { międzynarodowym, pozostałe } \\
\text { krajowe }\end{array}$ & & Los Angeles (USA) \\
\hline \multicolumn{3}{|c|}{ E. Systemy sześciolotniskowe } \\
\hline $\begin{array}{l}\text { E1. Wszystkie porty z ruchem } \\
\text { międzynarodowym }\end{array}$ & & Londyn (Wielka Brytania) \\
\hline \multicolumn{3}{|c|}{ F. Systemy siedmiolotniskowe } \\
\hline $\begin{array}{l}\text { F1. Trzy porty z ruchem } \\
\text { międzynarodowym, pozostałe } \\
\text { krajowe }\end{array}$ & & Nowy Jork (USA) \\
\hline
\end{tabular}

Źródło: opracowanie własne na podstawie informacji publikowanych przez porty lotnicze.

Objaśnienia: Kolombo (Sri Lanka) - układ wielolotniskowy powstały w wyniku relokacji portu głównego przy utrzymaniu działalności portu w pierwotnej lokalizacji; Panama (Panama) - układ wielolotniskowy z portem cywilnym powstałym na bazie lotniska wojskowego; Melbourne (Australia) - układ zawierający zarówno relokowany port główny jak i lotnisko cywilne powstałe na bazie wojskowego 
wiadającej przepustowości portu lotniczego wpływa negatywnie na jakość oferowanych w nim usług (Suarez-Aleman, Jimenez 2016). Opóźnienia w wykonywaniu operacji lotniczych oraz zatłoczenie terminali nie wpływa korzystnie na wizerunek portu i w warunkach silnej konkurencji może przyczyniać się do utraty pasażerów.

Potrzeba rozbudowy infrastruktury transportu lotniczego w sytuacji deficytu wolnej przestrzeni w miejscu jego pierwotnej lokalizacji może ostatecznie oznaczać konieczność relokacji portu lotniczego do miejsca, w którym tego rodzaju bariery nie istnieją. Właśnie taka sytuacja może prowadzić do powstania systemu wielolotniskowego. Może on stanowić jedynie formę przejściową - jeśli relokacja docelowo ma być całkowita i wiąże się z przeniesieniem całego ruchu lotniczego do nowego portu i zamknięciem starego, ale przez pewien czas funkcjonują równolegle. Budowa zupełnie nowego portu lotniczego nie musi być nastawiona na całkowite zastąpienie dotychczasowego. W takiej sytuacji nowy port lotniczy przeważnie przejmuje rolę portu głównego (np. Goeteborg). Tymczasem ten funkcjonujący w pierwotnej lokalizacji wprawdzie pozostaje aktywny, ale najczęściej traci udział w strukturze węzła jeśli chodzi o wielkość obsługi ruchu pasażerskiego.

Inna ścieżka rozwoju systemu wielolotniskowego wiąże się z zapotrzebowaniem na port lotniczy odpowiadający potrzebom przewoźników realizujących niskobudżetowy model biznesowy. Tanie linie lotnicze ograniczają koszty nie tylko zmniejszając zakres usług objętych ceną biletu czy zwiększając liczbę miejsc w samolocie, ale również korzystając z lotnisk stosujących niższe opłaty handlingowe (Alderighi i in. 2012) lub za lądowanie (Dudas 2010). Niższe opłaty stosują najczęściej porty charakteryzujące się peryferyjną lokalizacją, chcąc w ten sposób ściągnąć przewoźników. Tego rodzaju mechanizm doprowadził do powstania przywołanych już wcześniej portów drugorzędnych. Stanowią one albo część systemu wielolotniskowego obsługującego miasto, albo samodzielnie obsługują potrzeby transportowe $w$ tej dziedzinie np. jako port regionalny.

\section{Lokalizacja i charakterystyka systemów wielolotniskowych na świecie}

W latach 1995-2015 liczba systemów wielolotniskowych na świecie wzrosła z 47 do 67 (tab. 2). Wzrost nastąpił przede wszystkim w grupie tych węzłów lotniczych, które tworzą dwa porty. Przypada to na czas szczególnych (zwłaszcza w Europie) postępów w liberalizacji transportu lotniczego. Rok 1995 jest o tyle ważnym punktem odniesienia, że właśnie wtedy przewoźnicy tacy jak Ryanair (bezpośrednio wzorem amerykańskich linii Southwest) oraz easyJet weszli na drogę niskokosztowego modelu biznesowego (Dobruszkes 2013). Jak zwrócono uwagę wcześniej - ich pojawienie się a następnie szeroka popularyzacja przyczyniło się do rozwoju dedykowanej im sieci portów.

Systemy wielolotniskowe służące obsłudze miast w zakresie lotniczych potrzeb transportowych rozwinęły się na wszystkich kontynentach (ryc. 1). Ich lokalizacja wykazuje jednak silną koncentrację na trzech obszarach. Pierwszy stanowią Stany Zjednoczone, gdzie aż 16 miast obsługiwanych jest właśnie przez systemy wielolotniskowe. Obok miast światowych takich jak Nowy Jork czy Los Angeles, tego typu rozwiązaniem cieszą się również znacznie mniejsze ośrodki, np. Norfolk.

Za drugi obszar koncentracji można uznać Europę, z silną wewnętrzną dysproporcją. W przypadku państw zachodniej części kontynentu węzły zorganizowane na zasadach systemu wielolotniskowego występują znacznie częściej i nie ograniczają się do ośrodków stołecznych. Tymczasem w Europie Środkowej i Wschodniej tego typu rozwiązanie jest rzadkością i dotyczy wyłącznie stolic - Warszawy, Kijowa i Moskwy. Warto w tym miejscu odnotować, że tego rodzaju ośrodkiem był dawniej również Bukareszt. Aktualnie jedynym lotniskiem obsługującym rozkładowe połączenia do rumuńskiej stolicy jest Otopeni (im. Henri Coanda). Tymczasem drugi port - Băneasa (im. Aurel Vlaicu) od 2013 roku wykorzystywany jest wyłącznie dla obsługi lotów biznesowych, chociaż od 2007 do 2012 roku był intensywnie użytkowany przez przewoźników niskokosztowych, osiągając w 2011 roku wynik ok. 2,4 mln pasażerów.

Trzeci obszar koncentracji to Daleki Wschód, Indochiny i Malaje. Jest to zarówno teren dynamicznej urbanizacji, a także rozwoju transportu lotniczego dyktowanego $w$ dużej mierze wielkim potencjałem demograficznym oraz rozwojem turystyki. Tutaj również o pojawieniu się portów drugorzędnych w dużej mierze zadecydowała liberalizacja i duża aktywność przewoźników niskokosztowych. Tego rodzaju ścieżka rozwoju systemu wielolotniskowego wystąpiła w przypadku ośrodków południowoamerykańskich, takich jak np. Sao Paulo, Rio de Janeiro czy Buenos Aires.

Znaczenie rozwiązań takich jak omawiane systemy wielolotniskowe dodatkowo ilustruje analiza hierarchii portów lotniczych skonfrontowana z hierarchią uwzględniającą osiągnięcia całych systemów. Przy skumulowaniu liczby pasażerów wszystkich tworzących je lotnisk okazuje się, że w hierarchii węzłów lotniczych bezwzględnie dominują właśnie ośrodki wielolotniskowe (tab. 3). W grupie dwudziestu naj- 
Tab. 2. Liczba systemów wielolotniskowych na świecie w latach 1995-2015

\begin{tabular}{|l|r|r|r|r|r|}
\hline Wielkość układu wielolotniskowego & $\mathbf{1 9 9 5}$ & $\mathbf{2 0 0 0}$ & $\mathbf{2 0 0 5}$ & $\mathbf{2 0 1 0}$ & $\mathbf{2 0 1 5}$ \\
\hline Dwulotniskowy & 33 & 39 & 45 & 48 & 50 \\
\hline Trójlotniskowy & 9 & 9 & 10 & 11 & 11 \\
\hline Czterolotniskowy & 2 & 3 & 3 & 3 & 3 \\
\hline Pięciolotniskowy & 2 & 2 & 2 & - & 1 \\
\hline Sześciolotniskowy & - & - & - & 1 & 1 \\
\hline Siedmiolotniskowy & 1 & 1 & 1 & 64 & 67 \\
\hline RAZEM & 47 & 54 & 60 & & 1 \\
\hline
\end{tabular}

Źródło: opracowanie własne.

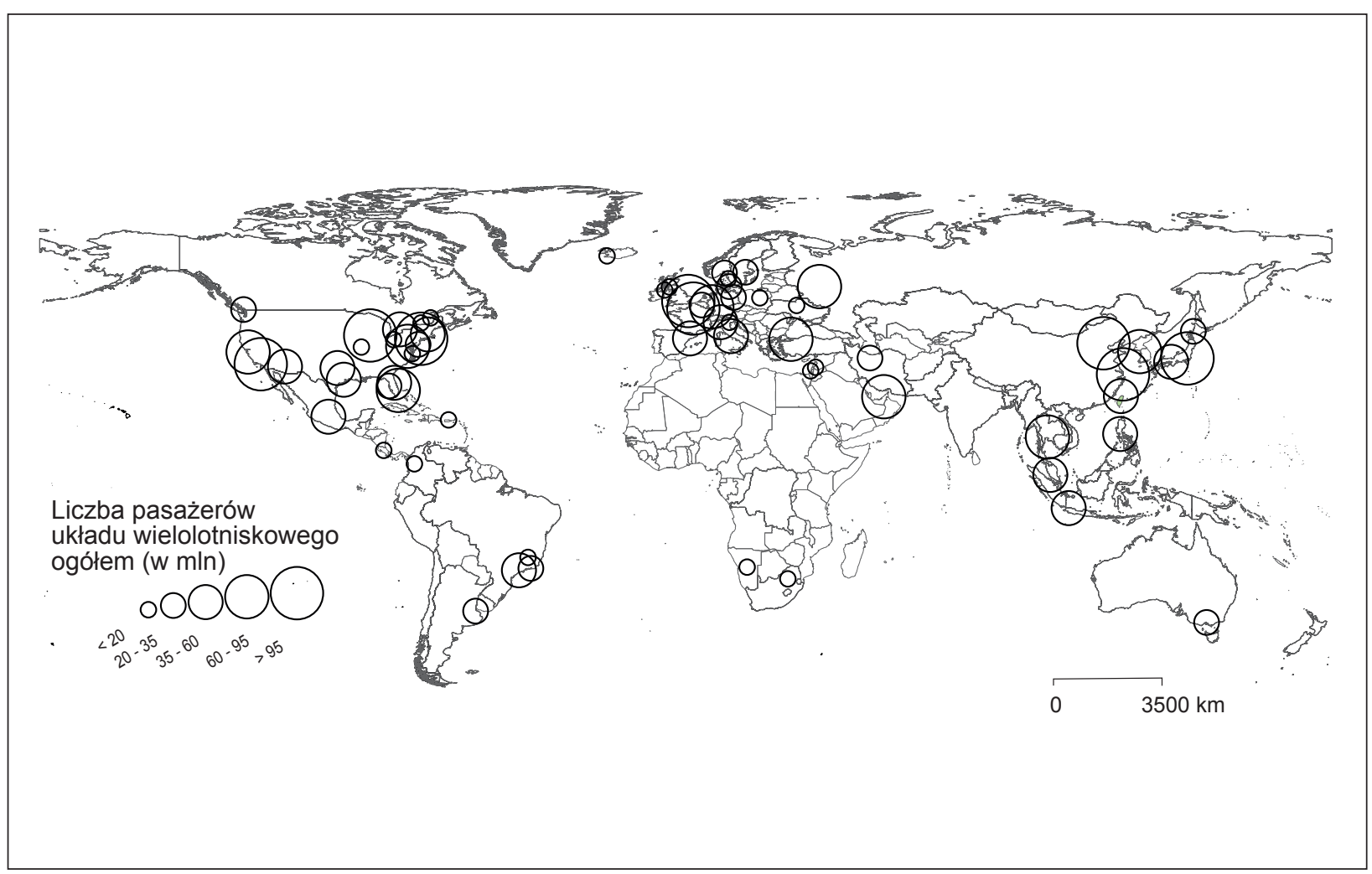

Ryc. 1. Liczba pasażerów w wielolotniskowych systemach na świecie.

Źródło. Opracowanie własne.

ważniejszych węzłów jedynie dwa (Atlanta i Amsterdam) obsługiwane są przez pojedynczy port.

Trudno wskazać wzorzec miasta, które byłoby predysponowane do rozwinięcia funkcji węzła lotniczego w ten sposób. Chociaż na liście miast obsługiwanych przez systemy wielolotniskowe przeważają duże ośrodki, to nie jest jednak możliwe wskazanie wielkości miasta, której przekroczenie wymusza takie rozwiązanie. Trzeba bowiem zauważyć, że niektóre bardzo duże miasta takie jak Madryt, Ateny, Helsinki czy Budapeszt obsługiwane są przez jeden port lotniczy.

\section{Przekształcenia systemów wielolotniskowych w latach 1995-2015}

W Europie rozwój systemów wielolotniskowych powiązany jest ściśle z procesem liberalizacji transportu lotniczego. Świadczy o tym wzrost liczby układów, które zawierają przynajmniej jeden port zdominowany przez przewoźników niskokosztowych. Jest to również grupa portów, która zyskała duże znaczenie w strukturze obsługi ruchu pasażerskiego. Wyraźnie ilustruje to przykład Brukseli i wzrost udziału portu drugorzędnego (Charleroi) z 0,3 do 22,9\% czy War- 
Tab. 3. Największe porty lotnicze a największe systemy wielolotniskowe świata

\begin{tabular}{|c|c|c|c|c|c|c|c|c|c|}
\hline \multicolumn{4}{|c|}{$\begin{array}{l}\text { Największe porty lotnicze świata } \\
\text { według liczby pasażerów }\end{array}$} & \multicolumn{3}{|c|}{$\begin{array}{c}\text { Największe systemy } \\
\text { wielolotniskowe świata według } \\
\text { liczby pasażerów }\end{array}$} & \multicolumn{3}{|c|}{$\begin{array}{l}\text { Miasta według liczby pasażerów we } \\
\text { wszystkich portach lotniczych }\end{array}$} \\
\hline Lp. & $\begin{array}{l}\text { Nazwa portu } \\
\text { lotniczego }\end{array}$ & $\begin{array}{l}\text { Obsługiwane } \\
\text { miasto }\end{array}$ & $\begin{array}{l}\text { Liczba } \\
\text { pasażerów } \\
\text { w mln }\end{array}$ & Lp. & Miasto & $\begin{array}{l}\text { Liczba } \\
\text { pasażerów } \\
\text { w mln }\end{array}$ & Lp. & Miasto & $\begin{array}{l}\text { Liczba } \\
\text { pasażerów } \\
\text { w mln }\end{array}$ \\
\hline 1 & $\begin{array}{l}\text { Hartsfield-Jackson } \\
\text { Atlanta Int. }\end{array}$ & Atlanta & 101,5 & 1 & Londyn & 152,8 & 1 & Londyn & 152,8 \\
\hline 2 & $\begin{array}{l}\text { Beijing Capital } \\
\text { International }\end{array}$ & Pekin & 89,9 & 2 & Nowy Jork & 119,6 & 2 & Nowy Jork & 119,6 \\
\hline 3 & Dubai International & Dubaj & 78,0 & 3 & Tokio & 112,6 & 3 & Tokio & 112,6 \\
\hline 4 & O'Hare International & Chicago & 76,9 & 4 & Szanghaj & 100,1 & 4 & Atlanta & 101,5 \\
\hline 5 & Tokyo Haneda & Tokio & 75,3 & 5 & Paryż & 99,8 & 5 & Szanghaj & 100,1 \\
\hline 6 & London Heathrow & Londyn & 75,0 & 6 & Chicago & 99,4 & 6 & Paryż & 99,8 \\
\hline 7 & $\begin{array}{l}\text { Los Angeles } \\
\text { International }\end{array}$ & Los Angeles & 74,7 & 7 & Los Angeles & 95,8 & 7 & Chicago & 99,4 \\
\hline 8 & $\begin{array}{l}\text { Hong Kong } \\
\text { International }\end{array}$ & Hong Kong & 68,3 & 8 & Pekin & 95,2 & 8 & Los Angeles & 95,8 \\
\hline 9 & $\begin{array}{l}\text { Paris-Charles de } \\
\text { Gaulle }\end{array}$ & Paryż & 65,8 & 9 & Stambuł & 89,4 & 9 & Pekin & 95,2 \\
\hline 10 & $\begin{array}{l}\text { Dallas/Fort Worth } \\
\text { International }\end{array}$ & Dallas & 64,0 & 10 & Bangkok & 83,1 & 10 & Stambuł & 89,4 \\
\hline 11 & Istanbul Atatürk & Stambuł & 61,8 & 11 & Dubaj & 78,0 & 11 & Bangkok & 83,1 \\
\hline 12 & Frankfurt & Frankfurt nad M. & 61,0 & 12 & Moskwa & 78,0 & 12 & Dubaj & 78,0 \\
\hline 13 & $\begin{array}{l}\text { Shanghai Pudong } \\
\text { International }\end{array}$ & Szanghaj & 60,0 & 13 & Miami & 77,5 & 13 & Moskwa & 78,0 \\
\hline 14 & $\begin{array}{l}\text { Amsterdam Airport } \\
\text { Schiphol }\end{array}$ & Amsterdam & 58,3 & 14 & Seul & 72,4 & 14 & Miami & 77,5 \\
\hline 15 & $\begin{array}{l}\text { John F. Kennedy } \\
\text { International } \\
\end{array}$ & Nowy Jork & 56,8 & 15 & San Francisco & 71,1 & 15 & Seul & 72,4 \\
\hline 16 & Singapore Changi & Singapur & 55,4 & 16 & Waszyngton & 68,5 & 16 & San Francisco & 71,1 \\
\hline 17 & $\begin{array}{l}\text { Guangzhou Baiyun } \\
\text { International }\end{array}$ & Guangzhou & 55,2 & 17 & $\begin{array}{l}\text { Frankfurt } \\
\text { nad M. }\end{array}$ & 63,7 & 17 & Waszyngton & 68,5 \\
\hline 18 & $\begin{array}{l}\text { Soekarno-Hatta } \\
\text { International }\end{array}$ & Dżakarta & 54,0 & 18 & Sao Paulo & 58,2 & 18 & Frankfurt nad $\mathrm{M}$. & 63,7 \\
\hline 19 & $\begin{array}{l}\text { Denver } \\
\text { International }\end{array}$ & Denver & 54,0 & 19 & Dallas & 57,5 & 19 & Amsterdam & 58,3 \\
\hline 20 & Suvarnabhumi & Bangkok & 52,8 & 20 & Houston & 55,1 & 20 & Sao Paulo & 58,2 \\
\hline
\end{tabular}

Źródło: opracowanie własne na podstawie danych publikowanych przez porty lotnicze.

szawy gdzie w krótkim czasie Modlin uzyskał 18,8\% udział (tab. 4A).

Wzrost znaczenia portów drugorzędnych jest wyraźnie większy w przypadku węzłów europejskich niż amerykańskich. Zwłaszcza w przypadku systemów wielolotniskowych obsługujących miasta Stanów Zjednoczonych udział ten można uznać za ustabilizowany (tab. 4B). Jednocześnie $w$ tym przypadku niekiedy trudno jest jednoznacznie wskazać, który z portów ma charakter głównego, a który drugorzędnego. Najlepszy przykład to Waszyngton, gdzie wszystkie trzy porty lotnicze obsługują porównywalną bliską 1/3 część ruchu pasażerskiego.

Na pozostałych kontynentach (zwłaszcza w Azji) skala zmian struktury węzłów wielolotniskowych była największa (tab. 4C). W tym przypadku najczęściej wynikało to z procesu relokacji głównego portu lotniczego i pozostawienia tego w pierwotnej lokalizacji np. do obsługi linii niskokosztowych lub krajowego transportu pasażerskiego.

\section{Systemy wielolotniskowe czy aerotropolis?}

Obsługa potrzeb transportowych wielkich miast stanowi jeden $z$ warunków ich rozwoju (Smith, Timberlake 2001). W skali powiązań międzynarodowych to właśnie na transporcie lotniczym spoczywa ciężar prawidłowego funkcjonowania danego ośrodka w sieci centrów decyzyjnych. Systemy wielolotniskowe 
Tab. 4A. Układy wielolotniskowe w Europie

\begin{tabular}{|c|c|c|c|c|c|c|}
\hline \multirow{2}{*}{$\begin{array}{c}\text { Typ } \\
\text { układu }\end{array}$} & \multirow{2}{*}{ Węzeł lotniczy } & \multicolumn{2}{|c|}{$\begin{array}{c}\text { Liczba pasażerów } \\
\text { ogółem }\end{array}$} & \multirow{2}{*}{$\begin{array}{l}\text { Porty lotnicze tworzące } \\
\text { układ wielolotniskowy }\end{array}$} & \multicolumn{2}{|c|}{ Udział w obsłudze węzła } \\
\hline & & 1995 & 2015 & & 1995 & 2015 \\
\hline \multirow{24}{*}{ 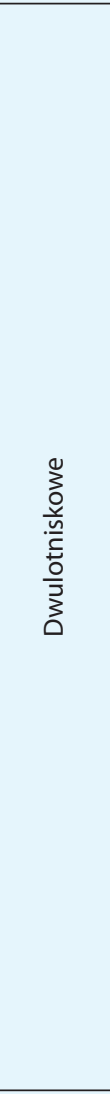 } & \multirow{2}{*}{ Belfast (Wielka Brytania) } & \multirow{2}{*}{3,6} & \multirow{2}{*}{7,1} & Belfast International & 64,7 & 62,0 \\
\hline & & & & George Best Belfast City & 35,3 & 38,0 \\
\hline & \multirow{2}{*}{ Berlin (Niemcy) } & \multirow{2}{*}{10,2} & \multirow{2}{*}{29,5} & Berlin Tegel & 80,8 & 71,1 \\
\hline & & & & Berlin Schönefeld & 19,2 & 28,9 \\
\hline & \multirow{2}{*}{ Bruksela (Belgia) } & \multirow{2}{*}{12,6} & \multirow{2}{*}{30,4} & Brussels Airport & 99,7 & 77,1 \\
\hline & & & & South Charleroi Airport & 0,3 & 22,9 \\
\hline & \multirow{2}{*}{$\begin{array}{l}\text { Frankfurt nad Menem } \\
\text { (Niemcy) }\end{array}$} & \multirow[t]{2}{*}{38,2} & \multirow[t]{2}{*}{63,7} & Frankfurt & 99,99 & 95,8 \\
\hline & & & & Frankfurt-Hahn & 0,01 & 4,2 \\
\hline & \multirow{2}{*}{ Glasgow (Wlk. Brytania) } & \multirow{2}{*}{5,9} & 93 & Glasgow & 93,9 & 93,5 \\
\hline & & & $\begin{array}{l}9,3 \\
\end{array}$ & Glasgow Prestwick & 6,1 & 6,5 \\
\hline & Götahora (S Zupcia) & & 6 & Göteborg Landvetter & 100,0 & 99,9 \\
\hline & Goteborg (szwecja) & 3,2 & 6,2 & Göteborg City Airport & & 0,1 \\
\hline & Kiión (Ukraino) & 12 & 2 & Boryspil International & 100,0 & 88,5 \\
\hline & Kljow (UKraina) & 1,3 & 8,2 & Kyiv Zhuliany International & & 11,5 \\
\hline & & & & Copenhagen & 99,7 & 99,9 \\
\hline & Kopenhaga (Danıa) & 15,1 & 26,6 & Roskilde & 0,3 & 0,1 \\
\hline & Revkiavík (Islandia) & 1,3 & 5,2 & Keflavík & 72,4 & 92,6 \\
\hline & neykjavik (IStaniura) & & & Reykjavík & 27,6 & 7,4 \\
\hline & Rzym (Włochy) & 218 & 463 & Fiumicino & 96,5 & 87,4 \\
\hline & Rzym (vvłocny) & 21,8 & 46,3 & Ciampino & 3,5 & 12,6 \\
\hline & & 2,7 & 13,8 & Warsaw Chopin & 100,0 & 81,2 \\
\hline & Warszawa (Polska) & & & Warsaw-Modlin Mazovia & & 18,8 \\
\hline & Wenecia (W/tochv) & 25 & 111 & Venice Marco Polo & 97,6 & 78,6 \\
\hline & venecja (vviocny) & 2,3 & 11,1 & Treviso & 2,4 & 21,4 \\
\hline & & & & El Prat & 92,1 & 94,1 \\
\hline & Barcelona (Hiszpania) & 12,7 & 42,2 & Girona & 4,1 & 4,2 \\
\hline & & & & Reus & 3,7 & 1,7 \\
\hline & & & & Malpensa & 25,9 & 48,0 \\
\hline & Mediolan (Włochy) & 15,0 & 38,7 & Linate & 71,9 & 25,0 \\
\hline & & & & II Caravaggio & 2,2 & 26,9 \\
\hline $\begin{array}{l}3 \\
0 \\
2 \\
2\end{array}$ & & & & Sheremetyevo & 48,7 & 40,5 \\
\hline$\frac{\bar{n}}{\underline{E}}$ & Moskwa (Rosja) & 17,3 & 78,0 & Domodedovo & 26,1 & 39,2 \\
\hline$\frac{0}{\overline{0}}$ & & & & Vnukovo & 25,2 & 20,3 \\
\hline & & & & Gardermoen & 98,7 & 88,6 \\
\hline & Oslo (Norwegia) & 10,7 & 27,9 & Torp & 1,3 & 5,5 \\
\hline & & & & Rygge & & 5,9 \\
\hline & & & & Charles de Gaulle & 51,4 & 65,9 \\
\hline & Paryż (Francja) & 55,1 & 99,8 & Orly & 48,4 & 29,7 \\
\hline & & & & Beauvais & 0,1 & 4,3 \\
\hline & & & & Arlanda & 93,7 & 84,3 \\
\hline 定 & & & & Bromma & 5,7 & 9,1 \\
\hline 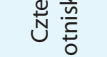 & Sztokholm (Szwecja) & 14,4 & 27,4 & Skavsta & & 6,6 \\
\hline & & & & Västerås & 0,6 & \\
\hline & & & & Heathrow & 65,4 & 49,0 \\
\hline $\begin{array}{l}3 \\
0 \\
\end{array}$ & & & & Gatwick & 27,1 & 26,3 \\
\hline$\stackrel{\underline{n}}{E}$ & I nndyn (Wielka Rrytania) & 833 & 1528 & Stansted & 4,7 & 13,0 \\
\hline$\frac{0}{\frac{0}{4}}$ & Lonayn (vvelka Brytania) & 83,3 & 152,8 & Luton & 2,2 & 8,0 \\
\hline ֻूN & & & & City Airport & 0,7 & 2,8 \\
\hline & & & & Southend & & 0,7 \\
\hline
\end{tabular}

Źródło: opracowanie własne na podstawie danych publikowanych przez porty lotnicze. 
Tab. 4B. Układy wielolotniskowe w Ameryce Północnej i Południowej

\begin{tabular}{|c|c|c|c|c|c|c|}
\hline \multirow{2}{*}{$\begin{array}{l}\text { Typ } \\
\text { układu }\end{array}$} & \multirow{2}{*}{ Węzeł lotniczy } & \multicolumn{2}{|c|}{$\begin{array}{l}\text { Liczba pasażerów } \\
\text { ogółem }\end{array}$} & \multirow{2}{*}{$\begin{array}{l}\text { Porty lotnicze tworzące } \\
\text { układ wielolotniskowy }\end{array}$} & \multicolumn{2}{|c|}{ Udział w obsłudze węzła } \\
\hline & & 1995 & 2015 & & 1995 & 2015 \\
\hline \multirow{36}{*}{ 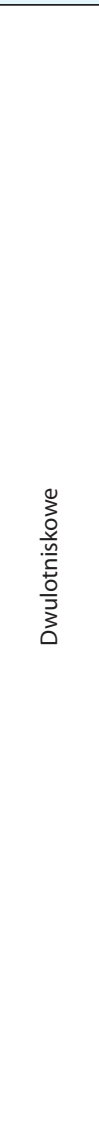 } & \multirow{2}{*}{ Belo Horizonte (Brazylia) } & \multirow{2}{*}{2,2} & \multirow{2}{*}{12,0} & Tancredo Neves International & 59,0 & 94,1 \\
\hline & & & & Pampulha - Carlos Drummond de Andrade Airport & 41,0 & 5,9 \\
\hline & \multirow{2}{*}{ Buenos Aires (Argentyna) } & & \multirow{2}{*}{20,5} & Aeroparque Jorge Newbery & & 55,4 \\
\hline & & & & Ministro Pistarini International & & 44,6 \\
\hline & Cleveland (USA) & 116 & 96 & Cleveland Hopkins International & 96,5 & 84,1 \\
\hline & Clevelana (USA) & 11,6 & 9,6 & Akron-Canton & 3,5 & 15,9 \\
\hline & & & & Dallas/Fort Worth International & 78,4 & 74,8 \\
\hline & Dallas (USA) & 31,5 & $5 /, 5$ & Dallas Love Field & 21,6 & 25,2 \\
\hline & Houcton (USA) & 329 & 551 & George Bush Intercontinental & 75,1 & 77,9 \\
\hline & Houston (USA) & 32,9 & 53,1 & William P Hobby & 24,9 & 22,1 \\
\hline & & & & José María Córdova International & 76,5 & 86,4 \\
\hline & Medelin (Kolumbia) & 2,3 & 8,0 & Enrique Olaya Herrera & 23,5 & 13,6 \\
\hline & Meksvk (Meksvk) & 159 & 393 & Mexico City International & 99,7 & 97,8 \\
\hline & Meksyk (Meksyk) & 13,9 & 39,3 & Toluca International & 0,3 & 2,2 \\
\hline & & & & Norfolk International & 88,1 & 88,3 \\
\hline & Norfolk (USA) & 3,0 & 3,4 & Newport News/Williamsburg & 11,9 & 11,7 \\
\hline & Phoenix (USA) & 279 & 453 & Phoenix Sky Harbor International & 100,0 & 97,1 \\
\hline & Pnoenix (USA) & 21,9 & 43,3 & Phoenix-Mesa Gateway & & 2,9 \\
\hline & & & & Orlando International & 99,8 & 94,0 \\
\hline & Orlando (USA) & 22,5 & 41,3 & Orlando Sanford International & 0,2 & 6,0 \\
\hline & & & & Galeão International & 73,3 & 64,2 \\
\hline & Rio de Janeiro (Brazylia) & 8,3 & 26,4 & Santos Dumont & 26,7 & 35,8 \\
\hline & St I OUic (USA) & 257 & 128 & Lambert-St Louis International & 100,0 & 99,5 \\
\hline & St LouIs (USA) & 23,1 & 12,8 & MidAmerica St Louis & & 0,5 \\
\hline & & & & Juan Santamaría International & 100,0 & 99,5 \\
\hline & San Jose (Kostaryka) & 1,8 & 3,6 & Tobías Bolaños International & & 0,5 \\
\hline & San Juan (Puertorvko) & 92 & 86 & Luis Muñoz Marín International & 100,0 & 99,4 \\
\hline & san Juan (Puertoryko) & 9,2 & 8,6 & Fernando Luis Ribas Dominicci & & 0,6 \\
\hline & & & & Guarulhos International & 72,6 & 67,0 \\
\hline & Sao Paulo (Brazylıa) & $1 /, 4$ & 58,2 & Congonhas & 27,4 & 33,0 \\
\hline & Tamna (USA) & 125 & 204 & Tampa International & 91,3 & 92,3 \\
\hline & Iampa (USA) & 12,5 & 20,4 & St Petersburg-Clearwater International & 8,7 & 7,7 \\
\hline & & & & Vancouver International & 99,98 & 97,7 \\
\hline & Vanocuver (Kanada) & 12,2 & 20,8 & Abbotsford International & 0,02 & 2,3 \\
\hline & & & & Toronto Pearson International & 99,4 & 94,4 \\
\hline & Toronto (Kanada) & 22,6 & 43,5 & Billy Bishop Toronto City Airport & 0,6 & 5,6 \\
\hline & & & & O'Hare International & 87,0 & 77,4 \\
\hline & Chicago (USA) & 77,3 & 99,4 & Midway & 12,8 & 22,4 \\
\hline & & & & Rockford & 0,2 & 0,2 \\
\hline & & & & Philadelphia International & 96,1 & 96,3 \\
\hline & Filadelfia (USA) & 19,2 & 32,6 & Atlantic City International & & \\
\hline 3 & & & & New Castle & 3,9 & 3,7 \\
\hline o & & & & Miami International & 68,3 & 57,2 \\
\hline$\stackrel{n}{E}$ & Miami (USA) & 48,1 & 77,6 & Fort Lauderdale & 20,5 & 34,7 \\
\hline 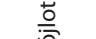 & & & & Palm Beach & 11,3 & 8,1 \\
\hline & & & & San Francisco International & 65,9 & 70,5 \\
\hline & San Francisco (USA) & 55,0 & 71,1 & Oakland & 17,9 & 15,8 \\
\hline & & & & San Jose & 16,2 & 13,8 \\
\hline & & & & Washington Dulles & 30,3 & 31,6 \\
\hline & Waszyngton (USA) & 41,1 & 68,5 & Ronald Reagan Washington & 37,7 & 33,6 \\
\hline & & & & Baltimore-Washington & 32,0 & 34,8 \\
\hline & & & & Logan International & 88,9 & 85,3 \\
\hline 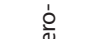 & Dostom & 202 & 200 & TF Green & 7,9 & 9,1 \\
\hline N & Boston (USA) & 28,3 & 39,2 & Manchester-Boston Regional & 3,2 & 5,3 \\
\hline & & & & Worcester Regional & & 0,3 \\
\hline & & & & Los Angeles International & 74,0 & 78,2 \\
\hline$\sum_{0}^{0}$ & & & & John Wayne & 9,8 & 10,6 \\
\hline 으요요 & Los Angeles (USA) & 72,8 & 95,8 & Ontario International & 8,8 & 4,4 \\
\hline$\underline{0}$ & & & & Bob Hope & 6,8 & 4,1 \\
\hline & & & & Long Beach & 0,6 & 2,6 \\
\hline & & & & John F Kennedy & 38,4 & 44,5 \\
\hline$\sum_{0}^{0}$ & & & & Newark & 33,5 & 29,8 \\
\hline 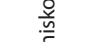 & & & & LaGuardia & 25,9 & 22,5 \\
\hline 등 & Nowy Jork (USA) & 79,4 & 119,6 & Westchester County & 1,2 & 1,2 \\
\hline$\stackrel{\circ}{\varepsilon}$ & & & & Long Island MacArthur & & 1,0 \\
\hline iv & & & & Trenton-Mercer & 0,05 & 0,6 \\
\hline & & & & Stewart International & 1,0 & 0,2 \\
\hline
\end{tabular}

Pozostałe układy wielolotniskowe (brak dostępnych statystyk): Montreal (Kanada), Panama (Panama)

Źródło: opracowanie własne na podstawie danych publikowanych przez porty lotnicze. 
Tab. 4C. Układy wielolotniskowe w Afryce, Australii i Azji

\begin{tabular}{|c|c|c|c|c|c|c|}
\hline \multirow{2}{*}{$\stackrel{\frac{2}{0}}{\frac{\pi}{2}}$} & \multirow[t]{2}{*}{ Węzeł lotniczy } & \multicolumn{2}{|c|}{ Liczba pasażerów ogółem } & \multirow{2}{*}{$\begin{array}{l}\text { Porty lotnicze tworzące układ } \\
\text { wielolotniskowy }\end{array}$} & \multicolumn{2}{|c|}{ Udział w obsłudze węzła } \\
\hline & & 1995 & 2015 & & 1995 & 2015 \\
\hline \multirow{26}{*}{ 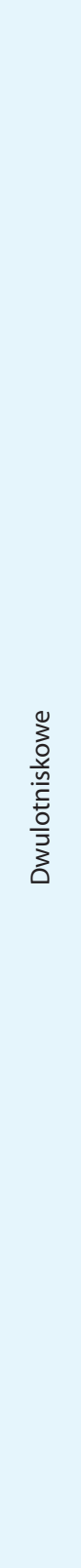 } & \multirow{2}{*}{ Bangkok (Tajlandia) } & \multirow{2}{*}{23,1} & \multirow{2}{*}{83,1} & Suvarnabhumi & & 63,7 \\
\hline & & & & Don Mueang International & 100,0 & 36,3 \\
\hline & \multirow{2}{*}{ Dżakarta (Indonezja) } & \multirow{2}{*}{13,9} & \multirow{2}{*}{54,4} & Soekarno-Hatta International & 94,8 & 99,6 \\
\hline & & & & Halim Perdanakusuma & 5,2 & 0,4 \\
\hline & \multirow{2}{*}{ Kuala Lumpur (Malezja) } & \multirow{2}{*}{12,8} & \multirow{2}{*}{52,0} & Kuala Lumpur International & & 94,1 \\
\hline & & & & Sultan Abdul Aziz Shah Airport & 100,0 & 5,9 \\
\hline & \multirow{2}{*}{ Manila (Filipiny) } & \multirow{2}{*}{10,6} & \multirow{2}{*}{37,9} & Ninoy Aquino International & 100,0 & 96,8 \\
\hline & & & & Clark International & & 3,2 \\
\hline & \multirow{2}{*}{ Pekin (Chiny) } & \multirow{2}{*}{15,0} & \multirow{2}{*}{95,2} & Beijing Capital International & 100,0 & 94,5 \\
\hline & & & & Beijing Nanyuan & & 5,5 \\
\hline & \multirow{2}{*}{ Sapporo (Japonia) } & \multirow{2}{*}{15,4} & \multirow{2}{*}{19,4} & New Chitose & 100,0 & 99,1 \\
\hline & & & & Okadama & & 0,9 \\
\hline & \multirow{2}{*}{ Seul (Korea Południowa) } & \multirow{2}{*}{30,9} & \multirow{2}{*}{72,4} & Incheon International & & 68,0 \\
\hline & & & & Gimpo International & 100,0 & 32,0 \\
\hline & \multirow{2}{*}{ Stambuł (Turcja) } & & & Istanbul Atatürk & 100,0 & 68,6 \\
\hline & & 12,1 & 09,4 & Sabiha Gökçen International & & 31,4 \\
\hline & & & & Shanghai Pudong International & & 60,9 \\
\hline & 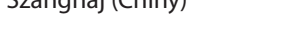 & 11,1 & 100,1 & Shanghai Hongqiao International & 100,0 & 39,1 \\
\hline & & & & Taiwan Taoyuan International & 55,1 & 86,8 \\
\hline & Idjpes (Idjwan) & 20,3 & $44, \mathrm{~S}$ & Taipei Songshan & 44,9 & 13,2 \\
\hline & & & & Ben Gurion & 91,0 & 95,7 \\
\hline & Tel AVIV (Izrael) & (כ, & 11,0 & Sde Dov & 9,0 & 4,3 \\
\hline & & & & Haneda & 65,4 & 66,9 \\
\hline & IOKIO (Japonla) & 10,0 & 112,6 & Narita International & 34,6 & 33,1 \\
\hline & & & & Hosea Kutako International & & 90,9 \\
\hline & 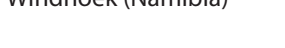 & & 0,9 & Eros & & 9,1 \\
\hline & & & & Kansai & 55,8 & 57,7 \\
\hline : & Osaka (Japonia) & 29,6 & 40,2 & Osaka International & 44,2 & 36,2 \\
\hline 흐 & & & & Kobe & & 6,1 \\
\hline & & & & Melbourne & 99,7 & 99,9 \\
\hline 旁 & & & & Essendon & 0,02 & 0,04 \\
\hline$\frac{\bar{z}}{0}$ & Meibourne (Australla) & 12,3 & 32,8 & Moorabbin & 0,03 & 0,03 \\
\hline N & & & & Avalon & & \\
\hline
\end{tabular}

Pozostałe układy wielolotniskowe (brak dostępnych statystyk): Amman (Jordania), Dubaj (ZEA), Johannesburg (RPA), Kolombo (SriLanka), Teheran (Iran)

Źródło: opracowanie własne na podstawie danych publikowanych przez porty lotnicze. 
nie są jedyną formą organizacji węzła lotniczego najważniejszych ośrodków. Dużą popularnością cieszą się również rozwiązania typu aerotropolis obsługujące chociażby Denver, Bangkok i Pekin. Zakładają one stworzenie wielkiego portu lotniczego równolegle z założeniem jednostki urbanistycznej zarówno służącej obsłudze portu jak i wykorzystaniu impulsów rozwojowych generowanych przez taki port (Kasarda 2010). Powstaje w ten sposób nowoczesne miasto, które wydaje się być doskonałą wizytówką całej metropolii. Można zatem odnieść wrażenie, że aerotropolis jest bardziej atrakcyjną formą w porównaniu $z$ rozproszonymi na terenie całej metropolii wieloma lotniskami. Tymczasem jednak zestawienie korzyści i wad obu rozwiązań pokazuje, że jednoznaczne wskazanie tego "lepszego" jest co najmniej trudne. Budowa portu o przepustowości znacznie wyprzedzającej aktualny poziom ruchu lotniczego pozwala zakładać, że przez relatywnie długi czas podobne inwestycje tego typu nie będą konieczne. Zaplanowanie przestrzeni pozwalającej na koncentrację pozytywnych efektów ekonomicznych generowanych przez wielki port dodatkowo wzmacnia rangę całego ośrodka. Jednocześnie funkcjonowanie systemu wielolotniskowego pozwala na uzyskanie szerokich korzyści wynikających z rozproszenia impulsów rozwojowych. Kilka portów lotniczych oznacza lokalizację działalności gospodarczej i generowanie zatrudnienia w większej liczbie lokalizacji. Funkcjonowanie aerotropolis spotyka się z krytyką również jako przykład monopolizacji. Tym samym system wielolotniskowy dzięki konkurencji między jego komponentami powinien przynosić korzyści korzystającym z niego pasażerom.

Wybór aerotropolis jako formy obsługi metropolii w zakresie jej potrzeb lotniczych poza samym aspektem transportowym oraz ekonomicznym oznacza także przedsięwzięcie o istotnym przekazie wizerunkowym. Symbolizuje zarówno olbrzymi potencjał ośrodka, który jest w stanie podołać tej skali kapitałochłonności inwestycji, a także podążanie za współczesnymi trendami myśli urbanistycznej. Tymczasem system wielolotniskowy w nie mniejszym stopniu stanowi dowód właśnie na metropolitalność ośrodka. Zgodnie z ideą sieciowej organizacji przestrzeni (Smętkowski 2009), rozmycie przestrzenne centrum oraz wzrost ahierarchicznych, zdecentralizowanych powiązań ośrodków o różnej wielkości stanowi cechę współczesnej metropolii. Tym samym właśnie funkcjonowanie kilku elementów węzła lotniczego w różnych lokalizacjach jak najbardziej odpowiada trendom rozwojowym współczesnych miast.

W kontekście przedstawionych wad i zalet obu rozwiązań nie sposób nie przywołać przykładu Ber- lina. W mieście chcącym walczyć o rangę ośrodka globalnego postanowiono porzucić dotychczasowy system wielolotniskowy na rzecz budowy aerotropolis na bazie portu Berlin Brandenburg, którego otwarcie planowano początkowo na jesień 2008 roku a do dziś nie udało się tych planów zrealizować. Za jedną z głównych przyczyn niepowodzeń a przede wszystkim znacznie wyższych niż pierwotnie planowano kosztów uznaje się zastosowanie niewłaściwego w stosunku do parametrów obiektu systemu ochrony przeciwpożarowej (Berlin Airport... 2014). Przykład ten może stanowić przestrogę dla ośrodków postrzegających swoją szansę na awans w globalnej sieci miast przez realizację takiej inwestycji.

\section{Podsumowanie}

Systemy wielolotniskowe stały się ważnym elementem światowego systemu portów lotniczych. Ich rozwój i funkcjonowanie nie jest jedynie zagadnieniem wartym uwagi z perspektywy transportowej. Jest nie mniej istotne w kontekście przekształceń przestrzeni miejskiej. Porty lotnicze stanowią czynnik intensywnie oddziałujący na przestrzeń społecznoekonomiczną. Jeżeli pojawia się ich w tej przestrzeni coraz więcej to oznacza to zwiększenie obszarów kształtowanych przez tego rodzaju impuls.

O przyszłości systemów wielolotniskowych w dużej mierze zadecyduje przyszłość korzystających z nich przewoźników. Dotychczas utrzymywanie ich w wielu przypadkach wynikało z innych potrzeb różnych grup linii lotniczych. Fakt, iż przewoźnicy niskobudżetowi coraz częściej wkraczają ze swoją ofertą do portów głównych mógłby w dalszej perspektywie oznaczać ograniczanie zapotrzebowania na specjalnie dedykowane im porty. Tymczasem jednak rośnie znaczenie przewoźników ultraniskokosztowych, którzy szukają jeszcze większych oszczędności w stosunku do linii niskobudżetowych (jak dotąd głównie na rynku amerykańskim: np. Allegiant Air, Frontier Airlines, Spirit Airlines), co oznacza, że zapotrzebowanie na tanie lotniska w systemach wielolotniskowych nie powinno przeminąć.

\section{Piśmiennictwo}

Alderighi M., Cento A., Nijkamp P., Rietveld P., 2012, Competition in the European aviation market: the entry of low-cost airlines, Journal of Transport Geography, 24, 223-233.

Berlin Airport: The five biggest mistakes, 2014, www.dw.com/ en/berlin-airport-the-five-biggest-mistakes/a-17740584.

Bonnefoy P.A., de Neufville R., Hansman R.J., 2008, Evolution and Development of Multi-Airport Systems: A Worldwide 
Perspective, Journal of Transportation Engineering, 136(11), $1-8$.

Derudder B., Devriendt L., Witlox F., 2010, A spatial analysis of multiple airport cities, Journal of Transport Geography, 18(3), 345-353.

Dobruszkes F., 2013, The geography of European low-cost airline networks: a contemporary analysis, Journal of Transport Geography, 28, 75-88.

Dudas G., 2010, Low-cost Airlines in Europe: Network Structures After the Enlargement of the European Union, Geographica Pannonica, 14(2), 49-58.

Fuellhart K., 2007, Airport catchment and leakage in a multiairport region: The case of Harrisburg International, Journal of Transport Geography, 15, 231-244.

Fuellhart K., O'Connor K., Woltemade Ch., 2013, Route-level passenger variation within three multi-airport regions in the USA, Journal of Transport Geography, 31, 171-180.

Harvey G., 1987, Airport choice in a multiple airport region Transportation Research Part A: General, 21(6), 439-449.

Hess S., Polak J.W., 2005, Mixed logit modelling of airport choice in multi-airport regions, Journal of Air Transport Management, 11(2), 59-68.

Ishii J., Jun S., van Dender K., 2009, Air travel choices in multiairport markets, Journal of Urban Economics, 65(2), 216227.

Kasarda J., 2010, Airport cities and the aerotropolis: The Way Forward, [w:] J. Kasarda (red.), Global airport cities, Insight Media, Londyn, 1-31.

Kołoś A., Taczanowski J., Trzepacz P., 2012, Connecting airports with cities. Perspectives of air-rail link development in Central Europe, Prace Geograficzne, 130, 107-130.

Lieshout R., 2012, Measuring the size of an airport's catchment area, Journal of Transport Geography, 25, 27-34.

Loo B.P.Y., 2008, Passengers' airport choice within multi-airport regions (MARs): some insights from a stated preference survey at Hong Kong International Airport, Journal of Transport Geography, 16, 117-125.

Maertens S., 2012, Estimating the market power of airports in their catchment areas - a Europe-wide approach, Journal of Transport Geography, 22, 10-18.

Martìn J.C., Voltes-Dorta A., 2011, The dilemma between capacity expansions and multi-airport systems: Empirical evidence from the industry's cost function, Transportation Research, 47(3), 382-389.

de Neufville R., 1995, Management of multi-airport systems: A development strategy, Journal of Air Transport Management, 2(2), 99-110.

Noruzoliaeea M., Zou B., Zhang A., 2015, Airport partial and full privatization in a multi-airport region: Focus on pricing and capacity, Transportation Research Part E: Logistics and Transportation Review, 77, 45-60.

Paliska D., Drobne S., Borruso G., Gardina M., Fabjan D., 2016, Passengers' airport choice and airports' catchment area analysis in cross-border Upper Adriatic multi-airport region, Journal of Air Transport Management, 57, 143-154.
Pels E., Nijkamp P., Rietveld P., 2003, Access to and competition between airports: a case study for the San Francisco Bay area, Transportation Research Part A: Policy and Practice, 37(1), 71-83.

Postorino M.N., Pratico F.G., 2012, An application of the MultiCriteria Decision-Making analysis to a regional multi-airport system, Research in Transportation Business \& Management, 4, 44-52.

Ramanujam V., Balakrishnan H., 2010, Estimation of arrivaldeparture capacity tradeoffs in multi-airport systems, Proceedings of the 48th IEEE Conference on Decision and Control, 2009 held jointly with the 2009 28th Chinese Control Conference, CDC/CCC 2009, https://dspace. mit.edu/handle/1721.1/58731 [dostęp: 14.12.2016]

Smętkowski M., 2009, Nowe relacje między metropolią a regionem: od terytorialnej do sieciowej organizacji przestrzeni, [w:] B. Jałowiecki (red.), Czy metropolia jest miastem?, Wydawnictwo Naukowe Scholar, Warszawa, 26-49.

Smith D.A., Timberlake M., 2001, World city networks and hierarchies, 1977-1997: An empirical analysis of global air travel links, American Behavioral Scientist, 44(10), 1656-1678.

Suarez-Aleman A., Jimenez J.L., 2016, Quality assessment of airport performance from the passengers' perspective, Research in Transportation Business \& Management, 20, 13-19.

Trzepacz P., Boruta T., Marada M., Quodomine R., 2012, Sto lat doświadczeń portów lotniczych w przestrzeni Europy, Prace Geograficzne, 131, 35-53.

Trzepacz P., Luc M., 2015, Użytkowanie ziemi w sąsiedztwie portów lotniczych Polski, [w:] P. Trzepacz, J. WięcławMichniewska, A. Brzosko-Sermak, A. Kołoś (red.), Miasto w badaniach geografów (tom 1), Wydawnictwo Instytutu Geografii i Gospodarki Przestrzennej UJ, Kraków, 315-334.

Zietsman D., Vanderschuren M., 2014, Analytic Hierarchy Process assessment for potential multi-airport systems - The case of Cape Town, Journal of Air Transport Management, $36,41-49$. 